\title{
RESOLVING ASBESTOS CLAIMS: THE MANVILLE PERSONAL INJURY SETTLEMENT TRUST
}

\author{
Marianna S. Smith*
}

\section{INTRODUCTION}

There was no precedent for the Manville Personal Injury Settlement Trust ("Trust"). A grantor trust, its genesis, birth, and evolution were influenced by-and its operation is still influenced by-many groups with differing agendas: the Manville Corporation, multiple federal and state courts, legal experts, investment bankers, victims' groups, plaintiffs' attorneys, Trust staff, and other trusts. The development and evolution of the Trust were further affected by a myriad of state and federal laws on, inter alia, trusts, securities regulation, contracts, fiduciary responsibility, bankruptcy, and civil procedure.

These often conflicting constituencies and laws were forced into a compromise "peace" during the upheaval of the Johns-Manville Corporation' chapter 11 bankruptcy filing. ${ }^{2}$

The Trust, an independent organization, was created by the bankruptcy court to distribute funds as equitably as possible while balancing the rights of

Copyright (C) 1990 by Law and Contemporary Problems

* Executive Director, Manville Personal Injury Settlement Trust.

This article was last revised in February 1991. In May 1991, Judge Jack B. Weinstein issued an order restructuring the finances and operating procedures of the Manville Personal Injury Settlement Trust.

1. In 1988 the Johns-Manville Corporation was renamed The Manville Corporation, and will be referred to hereafter as "Manville."

2. In December 1986, the United States Bankruptcy Court for the Southern District of New York approved a plan of reorganization ("Plan") for the Manville Corporation and related entities. See In the Matter of Johns-Manville Corporation, 68 Bankr 618 (Bankr SD NY 1986). See also Manville Corporation Second Amended and Restated Plan of Reorganization and Related Documents as Executed and Consummated at Plan Consummation C-80 to C-135 (November 28, 1988) (containing the Manville Personal Injury Settlement Trust Agreement) ("Second Amended Plan"). A cornerstone of the Plan was the creation of the Trust to compensate individuals suffering personal injury from exposure to asbestos or asbestos-containing products sold by the Manville Corporation. Following several appeals, the U.S. Court of Appeals for the Second Circuit confirmed the Plan on October 28, 1988. 843 F2d 636 (2d Cir 1988). The Trust became operational thirty days later on November 28, 1988.

Although Manville Corporation has not manufactured asbestos products since 1974 (with the exception of certain specialty products for the U.S. Department of Defense and the National Aeronautics Space Administration), asbestos-related diseases, such as asbestosis, lung cancer, and mesothelioma, can have substantial latency periods before symptoms appear. Thus, millions of American workers who were exposed to harmful asbestos fibers while asbestos was produced may only now be developing asbestos-related diseases. 
current claimants against those of future, unknown claimants. ${ }^{3}$ It was established as a negotiation-based settlement organization, designating its claimants as beneficiaries. (Co-defendants are also named beneficiaries.) Plan provisions made it clear that claimants did not need to litigate or threaten to litigate in order to negotiate a fair settlement. The Trust was committed to settling as many claims as quickly and fairly as possible in the order specified in the Plan. Although the Trust never wavered from this commitment, it quickly became clear that the full Plan would be impossible to implement.

During 1990-91, the Trust participated in a process initiated by the United States District Courts for the Eastern and Southern Districts of New York in an attempt to find a workable solution to the mismatch of available funds and volume of incoming claims. To preserve remaining Trust assets, the courts, under Judge Jack B. Weinstein, ordered the Trust to renegotiate its financial relationship with Manville Corporation and to revamp its claims handling procedures. At the heart of these efforts to restructure the liabilities and asseis of the Trust is a broad-based attempt to have a limited-fund class action certihed as a means to revise the rules governing the order and method of claims evaluation and payment.

At the time of this writing, the Trust's operations are governed by a stipulation of settlement filed on November 19,1990, and concurrent court orders staying Trust payments and settlements. ${ }^{4}$ The Plan's claims resolution procedures are soon to be replaced. Fairness hearings also are currently underway to determine whether all interested parties have been fairly represented and whether the Trust's claimants should be declared a class. As a final (nonappealable) court order redefining the Trust's mandates and procedures is not expected for some time, it is premature to discuss these procedures here. Rather, this article covers the genesis of the Trust, the process that formed it, and the Trust's unique attributes, strengths, and weaknesses. It concludes with a discussion of the lessons learned that can inform the design, implementation, and operation of future claims resolution facilities.

\section{The Manville Bankruptcy}

Between 1858 and the late 1970s, Johns-Manville Corporation produced more than 600 different asbestos products for a wide variety of industrial and construction needs. By the mid-1960s, when an epidemiological study documented the health dangers of asbestos exposure, Manville owned and operated several asbestos mines, and had thirty manufacturing plants in the United States and at least a controlling interest in eight overseas plants.

3. For the declared purposes of the Trust, see Second Amended Plan at C-80 par 2.02 (cited in note 2).

4. See Stipulation of Settlement and Orders to Show Cause, Findley v Blinken, NYAL 4000 (E \& SD NY, November 19, 1990). 
Manville made and sold asbestos products in three different forms: solid, as in exterior and interior insulation; soft or pliable, as in felt blankets, packing, and other material used to insulate boilers, steam engines, pipe joints, and air compressors; and granular or loose, as in a wide range of asbestos cements. These products were used in markets described by economists as "industrial" rather than "consumer," that is, Manville sold the products, primarily through distributors, to industries that used the products to make goods for later sale in the consumer market. Thus, the individuals most likely to be exposed to asbestos fibers through the handling of Manville's asbestos products were skilled, semi-skilled, and unskilled workers in a number of different industries and trades, including shipping, construction, insulation, utilities, oil and chemical refining, and manufacturing and maintenance of automobile parts, railroad cars, aerospace, and electrical equipment. During the 1960s, workers in these industries and trades began filing lawsuits against asbestos manufacturers, including Manville, alleging personal injury from asbestos exposure. By 1982, the lawsuits against Manville alone numbered more than 16,500, with more than 400 new cases filed each month. Projections at that time for the total number of Manville personal injury claimants ranged from 50,000 to $200,000 .^{5}$ This unexpected deluge of claims overwhelmed court dockets and confronted Manville with a then-estimated liability for personal injury claims in excess of $\$ 2$ billion through the year $2001 .^{6}$

In August 1982, Manville filed a petition for reorganization and protection under chapter 11 of the Bankruptcy Code, ${ }^{7}$ which automatically suspended all personal injury lawsuits and allowed Manville to reorganize, thus preserving its financial viability to compensate asbestos claimants.

\section{III}

\section{Establishment of The Trust}

The 1988 Plan of Reorganization represented four years of negotiation between the bankruptcy court, Manville, and the court-appointed representatives for existing asbestos claimants, future, unknown claimants, and co-defendants. To finalize the agreement, the negotiators, assisted by

5. By mid-January 1991 , the Trust had received more than 170,000 claims.

6. As with many significant corporate events, the myopia of time has caused corporate historians to remember events in different ways. There is some evidence, however, to support the majority corporate view that, after it had been sued in over 10,000 cases, Manville conducted its own epidemiological survey, which concluded that scores of thousands of additional plaintiffs would file personal injury actions against Manville requiring billions of dollars for defense costs and payments of judgments and settlements. After the new survey results were distributed to Manville's board of directors, the corporation's independent auditors took the position that the survey conclusions created a contingent liability, which, according to the Accounting Board Standards for General Purposes Accounting, had to be reflected on Manville's balance sheet. As with commercial creditors of most major corporations, Manville's commercial creditors had the right to accelerate repayment of their loans if Manville's balance sheet changed in a significant manner. Obviously, a $\$ 2$ billion contingent liability was such a significant change. Manville conducted informal talks with several of its major creditors, which contributed, in part, to Manville's declaration of bankruptcy.

7. 11 USC $\S \S 1101-1146$ (1982). 
legions of attorneys and financial advisors, were required to compromise on a wide range of extremely complicated financial and claims handling issues. Without the benefit of experts on management and claims settlement, the negotiators wrestled with various procedural questions, such as how quickly, in what priority, and through what approaches claims would be processed, evaluated, and settled.

Two goals were fundamental to the Plan's ultimate success: first, that the principles and strategies guiding the Trust's settlement of claims be fair to the parties, and, second, that the agreed-upon plan of reorganization be realistic and achievable. Only the first of these goals was met.

\section{A. Impact of a Trust Structure}

The Manville Trust is a grantor trust. During the design period, it was thought that tax benefits from a trust structure would be very beneficial to the grantor, Manville. The Internal Revenue Service subsequently carved out a special rule-the "Manville Rule" $-{ }^{8}$ to address the Trust's unique tax status. Since such a rule could have been attached to any organizational structure, such as non-profit, foundation, or charitable foundation, it was unnecessary to impose the significant encumbrances associated with a trust structure.

Probably the most unique characteristic of a trust is the strict accountability, and thus the liability, of the trustees. Whereas corporate directors are subject to a business rule of "reasonable business judgment," trustees are held to the "highest standards of care" in preserving and enhancing the trust estate and are subject to personal liability in the event they do not meet those standards. On paper, the trustees' unique accountability has merit. In the context of the lack of trust between those representing the injured claimants and Manville, the "higher standard of care" seemed a politic choice at the time. In practice, however, it creates financial and legal difficulties. For example, because of this unflinching accountability, the Trust must purchase separate liability insurance for its directors and officers (as trustees) at an annual premium cost of over $\$ 2$ million. In the absence of such insurance, trustees would be personally liable and unlikely to volunteer to take that risk. The Trust also must self-insure by segregating $\$ 30$ million of its assets as additional insurance protection. To reduce this financial sting, the Plan limits trustee accountability by specifying that trustees may be successfully sued only for gross negligence or willful misconduct. ${ }^{9}$ In practice, however, this limitation offers little comfort to anyone asked to serve as a trustee and thus put his or her personal fortune at risk.

The complexities associated with the trust structure are further complicated in the Manville Trust situation by the continuing jurisdiction of the bankruptcy court. The Trust, in effect, owns Manville. While there is

8. IRC $\S 382$, as revised by the transitional rule, Section 621 (I)(4) of the Tax Reform Act of 1986, Pub L No 99-514, 100 Stat 2085 (1986).

9. Second Amended Plan at C-85 par 5.04 (cited in note 2). 
adequate precedent on post-reorganization bankruptcy proceedings, there is little or no legal guidance for a trust that owns a post-reorganization company. Thus, the legal, procedural, and liability ramifications of every issue must be minutely examined and researched.

\section{B. The Operation of the Trust}

Although not confirmed until October 1988, the Trust began operation in January 1987, following the bankruptcy court's appointment of trustees. During the first seven months of 1987, several consulting organizations assisted the trustees in handling a range of complex issues and developing a strategy for responding to the impending deluge of claims. In October 1987, the trustees hired this author as executive director of the Trust, and shortly thereafter established the Trust's offices in Washington, D.C. Within six months, the Trust had hired and trained nearly ninety-five employees and was prepared to settle claims. ${ }^{10}$

In May 1988, the Trust began to negotiate settlements of the cases filed against Manville before August 1982, all of which had been stayed by the bankruptcy proceeding. Of the approximately 16,500 pre-bankruptcy claims submitted to the Trust, more than 15,500 were settled for a total of approximately $\$ 640$ million. Upon consummation of the plan on November 28,1988 , the Trust was able to begin paying these pre-bankruptcy claims, subject to certain conditions, including the receipt of an individual proof of claim form and a signed release from each claimant. By mid-1989, an additional 48,500 post-bankruptcy claim forms were received, for a total of 65,000 claims filed with the Trust. By the end of August 1989, the total had risen to more than 97,000 , and by January 1991 more than 170,000 claimants were seeking compensation from the Trust.

\section{The Protection of Multiple Interests and Beneficiaries}

The Trust has three principal groups of beneficiaries: present claimants, future claimants, and co-defendants. As fiduciaries, the trustees, who are responsible for supervising and administering the claims resolution facility, ${ }^{1}$ must treat the groups equally, showing no favoritism toward any one group despite the inherent conflicts. Such conflicts exist because, for example, claimants may be both Trust beneficiaries and litigants, and co-defendants are beneficiaries of the Trust as well as litigants of the Trust and of the claimants.

The Trust's directives to "enhance and preserve the Trust estate" in order to "deliver fair, adequate and equitable compensation to [claimants], whether known or unknown," and to give "full" compensation to all claimants ${ }^{12}$ give rise to additional conflicts. With insufficient assets to pay even the current, known claimants in full, the conflict is obvious.

10. As of January 1991, the Trust had approximately 110 full-time staff members.

11. Second Amended Plan at C-80 par 2.02 (cited in note 2).

12. Id. 


\section{Long-Term Funding Versus Immediate Liabilities}

The Trust is funded for twenty-seven years through a complicated array of financial instruments that form the unique financial relationship between the Trust and Manville. The Trust is Manville's principal stockholder, holding 24 million shares (50 percent) of common stock and 7.2 million shares of Manville series A convertible preferred stock, which is convertible into 72 million shares of common stock. ${ }^{13}$ After conversion, the Trust would own 80 percent of Manville's common stock. As holder of two bonds with an aggregate face value of more than $\$ 1.8$ billion, ${ }^{14}$ the Trust is also Manville's largest creditor. The total assets with which the Trust was funded have a face value well in excess of $\$ 3$ billion. Beginning in 1992 and continuing as long as the Trust needs additional funds, the Trust also will receive up to 20 percent of Manville's profits under a profit-sharing agreement. ${ }^{15}$

As part of the 1990 court-ordered restructuring, Manville and the Trust entered into agreements to enhance the Trust's available cash to pay claims. The Trust's funding mechanisms, both before and after more recent modifications, provide limited funds during early years with restrictions on the sale of assets, and insufficient funds in the aggregate to pay all claimants.

As noted above, the bankruptcy reorganization plan states that all claimants will receive payment from the Trust of 100 hundred percent of full value. When the value of present claims exceeded the value of available assets, it became clear the Trust could not meet that mandate. Even the attempt to do so would mean selling the Trust's asset, Manville stock, and would violate another requirement of the Plan: to preserve assets to pay future, as-yet-unfiled claims. Despite this requirement, the Plan provided no mechanism to hold back money for such a purpose.

\section{E. The Evaluation of Claims}

The Trust may compensate claimants only for injuries caused by exposure to Manville asbestos. Thus, the Plan mandates that each claim be evaluated on its own merits considering the nature and severity of the injury, as well as factors such as the extent of exposure to Manville products, exposure to other manufacturers' products, jurisdictional values, and the claimant's age, wage loss, and medical costs. ${ }^{16}$ So that the less costly, less risky settlement process provided by the Trust would be more attractive to claimants, the evaluation process was designed to consider the same factors that would be considered if settlement, award, and verdict values were derived through litigation.

Since many of the claims resolution procedures set forth in the Plan ${ }^{17}$ are expected to change dramatically under the class action settlement, it is inappropriate in this article to discuss the old structure and premature to

13. Id at C-111 par 3.01, C-113 par 3.02.

14. Id at C-110 par 2.02, C-128, C-132.

15. Id at C- 110 par 2.03.

16. Id at C-101.

17. See generally id at C-99 to C-107. 
discuss the new. Therefore, the remaining paragraphs in this section will discuss some of the more unusual legal and operational aspects of the Trust, independent of the procedures that are likely to change.

\section{F. Payments to Pre-Bankruptcy Claimants}

The bind in which the Trust found itself when it came time to pay the prebankruptcy claims illustrates the conflicts discussed in the previous section. The controversy did not surface, however, until early 1990 when the Trust announced an extended payment plan on current and future settlements, under which settlements were to be paid 40 percent at settlement and 60 percent over five years.

Despite extensive efforts to call the attention of the courts and the plaintiff bar to the critical shortfall of Trust assets available to pay claims, only the step away from 100 percent claims payments finally brought wide awareness of the problem. That awareness manifested itself, however, not by addressing the cash shortfall issue directly. Instead the discussion revolved around the amounts of the pre-bankruptcy settlements. In addition, the Trust was criticized for its decision to pay 100 percent on all pre-bankruptcy claims, even though the bankruptcy plan specified such and the decision was endorsed at the time by the parties to the bankruptcy. Many appeared to feel that the Trust had paid out too much, too soon, to the earliest claimants.

In its first year alone, the Trust disbursed over $\$ 600$ million to prebankruptcy claimants. While a large sum by anyone's measure, in perspective this amount is considerably less than it seems. Many of the 16,500 claimants were high-value, acute injury cases; some were "Manville-only" cases (for example, Manville plant workers), for which the Trust assumed full, rather than the usual partial, liability. Also driving up claim value was the long wait the pre-bankruptcy claimants had endured, a wait ranging from six to twelve years depending on their states' docket backlog.

Despite annual medical cost increases of 11.5 percent after 1982 , the Trust kept its average settlement value at $\$ 41,150$. Thus, the initial $\$ 600$ million represents less than 15,000 of the earliest, sickest claimants. At the time of Manville's 1982 bankruptcy filing. Trust planners estimated they would have to pay some 50,000 claimants $\$ 40,000$ each. A broader study conducted some years later estimated a greater number of claims at a lower cost per claim. As the Trust settles the "newer" claims, the lower estimate may yet be proven accurate.

\section{G. Litigation-Not Settlement-Driven}

Although heavy litigation against the Trust was not contemplated by the crafters of the reorganization plan, it was unavoidable, operationally unmanageable, and ultimately contributed substantially to the Trust's already troubled financial situation. As evidenced by one of the articulated purposes 
of the Trust, ${ }^{18}$ the crafters of the Plan genuinely wanted the Trust to be a negotiation-based settlement organization. They wanted claimants to explore all avenues of negotiation and alternative dispute resolution before turning to litigation as a last resort. To meet this objective, the Plan established a "formula" for ordering the payment of claims, allowing the Trust to take cases docketed and scheduled for trial out of queue and settle them. This appeared to be a reasonable approach. However, two factors led to the Trust's inundation with active litigation. The first factor was purely operational: the Plan permitted claimants to sue the Trust 120 days after filing their claims with the Trust. ${ }^{19}$ Because the Trust had received such an enormous volume of claims and was unable to make offers on all of them within 120 days, claimants had the right to sue and did so to improve their position in the queue.

The second factor influencing the volume of litigation was an acceleration in the volume of cases tried in the courts compared to the relative handful of asbestos cases that came to trial in the mid-1980s. By 1990 four significant class actions and tens of thousands of individual cases demanded judicial attention. As noted above, this deluge had not been anticipated, and the Plan did not allow modification of the Trust's operations to accommodate the problem.

\section{H. Settlement Transaction Costs}

The excessive unplanned litigation also had a significant financial impact on the Trust. Prior to July 1989, before the trial docket began to drive the Trust's business conduct, the cost of settling claims, or transaction cost (measured as operating costs, including start-up costs as a percentage of settlement values), was 6.1 percent of total costs. When litigation costs are excluded, this percentage drops only slightly to 5 percent. Even with the heavy impact of the trial docket, from inception of the Trust to the end of 1990, the Trust kept overall transaction costs to 10.4 percent. Transaction costs excluding litigation defense costs were kept to 5.5 percent of settlements. Had the Trust been able to avoid the cost of litigation defense, it would have offered a low-cost alternative to traditional settlement techniques.

18. Id at C-80 par 2.02 ("with settlement to be preferred over arbitration, arbitration to be preferred over resort to the tort system, and fair and efficient resolution of claims to be preferred over all else").

19. Id at C-102. Under the Plan's excruciatingly detailed and entirely unreasonable time constraints on the settlement process, the Trust must review claim forms within ten days of filing and then contest exposure within thirty days or make a written good faith offer of settlement within ninety days. The claimant then has ten days to respond. If the claimant makes a counter proposal, the Trust has ten days to respond, otherwise the Trust must issue a check within twenty days. Curiously, despite the strict response times, the sections defining the time periods begin with the words "to the extent practical" and include a complicating general proviso that "there shall be no artificial limitation on the number of claims handled in a given period of time." Id at C-100 to C-102. 


\section{IV}

\section{Lessons for Future Settlement Organizations}

As the Trust awaits final direction from the courts on how to proceed, it is a good time to reflect on how lessons learned by the Trust might serve to guide crafters of future claims resolution facilities.

A. Build In Flexibility. In crafting any plan, it is essential to articulate the plan's objectives and devise the procedures to implement the objectives. However, enough flexibility must exist during implementation to revise or replace operational approaches when they fail to promote their intended goals.

B. Authorize the Balance of Assets and Liabilities. When the ultimate liability of a mass tort is unknown, as will often be the case with toxic torts, and when lengthy disease latencies preclude the imposition of a cut-off date to limit the number of potential claims, the plan must authorize the balance of assets and liabilities in the most equitable and fair fashion. One viable solution to the Trust's difficulty would have been to offer partial payments, known as a pro-rata distribution. That proposal, now under consideration in the class action settlement, would distribute a share of the available cash to each settled claim based upon its proportionate value of total liability.

C. Protect Constitutional Rights. While no legal document may limit or deny constitutionally guaranteed protections (such as the right to trial), careful thought must be given to building incentives that promote the behavior patterns required for ultimate success of the settlement program. In particular, attention should focus on building disincentives for claimant alternatives such as litigation that will dissipate assets. The Trust is a prime example of a case where the right to trial became a driver rather than a fallback for claimants when all settlement approaches failed.

D. Simplify the Legal Structure. It is critical to minimize the bodies of law with which a new organization is burdened. The Manville Trust is subject to the law of all fifty states, as well as bankruptcy law, tort law and traditions, corporate and business law, rules of the Securities and Exchange Commission, and complex federal legislation. Unless a compelling reason to do so exists, placing the law of trusts in this mix is unnecessarily burdensome.

E. Consider Management Input During the Design Stage. When lawyers and judges without extensive business experience create procedural and operational documents, they must involve specialists, such as operations planners, management consultants, and organization designers, who know how to make organizations function in the real world. Experienced operations experts need to advise on the practicality of the organization design, and on its goals and flexibility. Reaching consensus through compromise can reap great 
initial benefits from a settlement perspective, but may lead to later failure in its practical implementation phase.

\section{$\mathrm{V}$}

\section{Conclusion}

Solutions to the Trust's dilemma are no more easily found now than they were in 1982. The same opposing forces are struggling over the same issues that were raised ten years ago. However, experience has shown at least two features of claims resolution facilties that do not work:

1. Allowing easy and immediate access to the tort system forces the Trust into a "courthouse steps settlement" posture, which is expensive, wastes assets, skews claims values artificially high, and neglects many needy beneficiaries.

2. Inconsistent and sometimes conflicting goals, written to achieve settlement through compromise, create confusion, delay, and additional litigation, slowing down or even halting operations.

There has been tremendous pressure from the media, the courts, and the Trust beneficiaries to provide an "answer" to the asbestos liability problem. Unfortunately, there is no quick, simple, or easy answer. To oversimplify these complex problems only will exacerbate them in the long run. Consideration of some of the painful lessons learned over the past three years of Trust operation will be critical to the success of future efforts. 